\title{
Focusing Anti-Corruption Efforts More Effectively: An Empirical Look at Offender Motivation-Positive, Classical, Structural and Ethical Approaches
}

\author{
Jay S. Albanese, Kristine Artello \\ Wilder School of Government \& Public Affairs, Virginia Commonwealth University, Richmond, VA, USA \\ Email: jsalbane@vcu.edu, kartello@vcu.edu
}

How to cite this paper: Albanese, J. S., \& Artello, K. (2018). Focusing Anti-Corruption Efforts More Effectively: An Empirical Look at Offender Motivation-Positive, Classical, Structural and Ethical Approaches. Advances in Applied Sociology, 8, 471-485. https://doi.org/10.4236/aasoci.2018.86028

Received: March 8, 2018

Accepted: June 17, 2018

Published: June 20, 2018

Copyright ( 92018 by authors and Scientific Research Publishing Inc. This work is licensed under the Creative Commons Attribution International License (CC BY 4.0).

http://creativecommons.org/licenses/by/4.0/ (c) (i) Open Access

\begin{abstract}
The level of public corruption cases remains high. Interviews with 72 former investigators, prosecutors, community stakeholders and individuals with first-hand experience in corrupt activities, together with analysis of court documents, offer insight into the motivations behind the corrupt conduct in hundreds of known corruption cases. Corrupt motivations are classified into four categories: positive, classical, structural, and ethical. Empirical examples from interviews and court cases are used to show how the identified causes and correlates of corruption can be grouped and use to develop more effective anti-corruption prevention strategies. Recommendations are offered to reduce the extent of corruption by applying the principles of positive, classical, structural, and ethical explanations of corruption to reduce opportunities for corruption and improve the integrity levels of those in public service.
\end{abstract}

\section{Keywords}

Corruption, Prevention, Ethics, Bribery, Causes of Corruption

\section{Introduction}

Public opinion surveys show that corruption is ranked as one of the most serious problems across the world (Deloitte, 2017; Tanzler, Konstadinos, \& Giannakouplos, 2016; Transparency International, 2011, 2017). Although concern about corruption is often externally focused on "other" cities and "other" countries, many people, even in countries with comparatively low corruption levels, see it 
as a significant problem to economic growth, government legitimacy, and effective rule of law (Belousova, Goel, \& Korhonen, 2016; Buscaglia \& Dakolias,1999; Cieslik \& Goczek, 2018; d'Agostino, Dunne, \& Pieronic, 2016).

The United States is no exception with Gallup surveys showing a majority of Americans believing that "quite a few" of the people running the government are the dishonest. Table 1 summarizes Gallup polling from 1992 to 2010. It shows that majority of US respondents believe that "quite a few" government officials are crooked, a trend that has been resilient over many years.

This survey's findings are consistent with other surveys (American National Election Studies, 2012). While the public clearly identifies public corruption as a significant issue, the motivations of such acts have had little empirical examination. In this study, the motivations to commit corrupt acts in the public sector are explored.

A generic definition of corruption is simple, but it can take two forms: "the abuse of public office for private gain" (World Bank, 1997) has been the most common definition, because corruption traditionally focuses on public corruption; that is, corruption that occurs in the public sector. Given the seriousness of commercial corruption, however, many now use an expanded definition: "the abuse of entrusted power for private gain” (Rose-Ackerman \& Palikfa, 2016; Transparency International, 2017; White, 2013). This second definition includes commercial corruption together with public corruption, even though a great deal of commercial corruption centers on consumer frauds and business-on-business crimes. Consequently, some commercial corruption directly involves the public interest, whereas all public corruption directly impacts the public interest (in that it includes nepotism, cronyism, official misconduct, obstruction of justice, embezzlement and related financial crimes). If a given public, governmental function or office is seen as the state's responsibility, a person "abusing that office for personal or group advantage is corrupt" (Holmes, 2015: p. 6).

A relativist argument posits that definitions of corrupt conduct vary by culture

Table 1. Gallup poll: trust in government.

\begin{tabular}{lccc}
\hline & \multicolumn{2}{c}{$\begin{array}{c}\text { Question: Do you think that quite a few of the people running the government are } \\
\text { crooked, not very many are, or do you think hardly any of them are crooked? }\end{array}$} \\
\cline { 2 - 4 } Year & Quite a few & $\begin{array}{c}\text { Not very } \\
\text { many/hardly any }\end{array}$ & All \\
\hline 2010 & 55 & 38 & 6 \\
2008 & 52 & 38 & 5 \\
2000 & 49 & 46 & 3 \\
1997 & 50 & 45 & 3 \\
1996 & 52 & 41 & 5 \\
1994 & 58 & 35 & 5 \\
1992 & 61 & 32 & 4 \\
\hline
\end{tabular}

Source: Gallup Poll (2010). 
and country, and sometimes even within countries. But both public opinion and a growing number of international agreements suggest that this is not the case. The OECD Convention, UN Convention against Corruption, and anti-money laundering agreements are examples of broad consensus about the precise limits of acceptable conduct in business and government (OECD Convention, 1999; Reider-Gordon, 2011; United Nations Convention on Corruption, 2005).

In addition, every culture distinguishes gifts from bribes by the intention of the giver, the expectation of the recipient, the value and timing of the gift. In every case, if the giver or receiver would not want the exchange to be known publicly, it is a bribe (Albanese, 2016; Carte \& Fox, 2004; Moldovan \& Van de Walle, 2013). Therefore, "cultural differences exist, but are often exaggerated" (Holmes, 2015: p. 7).

Public corruption is a more serious social problem than commercial corruption, because an individual or business who is unhappy with a corrupt arrangement with another individual or company can take their business elsewhere. Market competition makes it difficult for businesses to make demands on one another, or on consumers, that are burdensome. On the other hand, if an individual or business is unhappy with a corrupt arrangement in securing a government building permit, zoning decision, mandated inspection, contract, or official document, the government has a monopoly on these kinds of decisions, so there is nowhere for the individual or business to turn. Furthermore, in the case of individual-to-individual or business-to-business disputes, the government (through its enforcement, regulatory and court systems) is used as a neutral arbiter. When government agencies themselves are corrupt, however, individuals and businesses are victims without recourse. Hence, acts of public corruption affect every citizen, whereas commercial corruption affects some citizens.

\section{Types of Cases and Their Motives}

Corrupt acts can be grouped into two categories: grand and petty corruption. Grand corruption involves a small number of powerful participants and usually involves large sums of money. Petty corruption involves exchanges at lower levels of government and business (de Speville, 2016; Rose-Ackerman \& Palifka, 2016). Of course, these two categories oversimplify the situation, depending on the circumstances of the case. Figure 1 breaks out these two categories into the underlying behaviors, clarifying the precise kinds of conduct that distinguished more serious from less serious forms of corruption.

Empirical evidence supports this typology. An empirical analysis found 10 statutes comprised $60 \%$ of all the public corruption cases brought from 1986-2015 in the US. These statutes addressed three major types of underlying behavior: bribery, fraud, and extortion, illustrating the centrality of these kinds of conduct to corruption (Albanese, Artello, \& Nguyen, 2018).

Table 2 illustrates these common corruption behaviors by the level of government involved. The table shows how the frequency of different kinds of 
Table 2. Behaviors underlying corruption case by level of government.

\begin{tabular}{|c|c|c|c|c|}
\hline \multirow{2}{*}{$\begin{array}{l}\text { Underlying } \\
\text { behaviors }\end{array}$} & \multicolumn{4}{|c|}{ Level of government } \\
\hline & $\begin{array}{l}\text { Total } \\
\text { (rank) }\end{array}$ & $\begin{array}{c}\text { Federal } \\
\text { (rank) }\end{array}$ & $\begin{array}{l}\text { State } \\
\text { (rank) }\end{array}$ & $\begin{array}{l}\text { Local } \\
\text { (rank) }\end{array}$ \\
\hline Fraud & $8742(1)$ & $5579(1)$ & $2051(2)$ & $1112(2)$ \\
\hline Bribery & $8620(2)$ & $5129(2)$ & $2421(1)$ & $1070(3)$ \\
\hline Extortion & $3413(3)$ & $535(4)$ & $1722(3)$ & $1156(1)$ \\
\hline Conspiracy/racketeering & $2770(4)$ & $1420(3)$ & $896(4)$ & $454(4)$ \\
\hline Total & $\begin{array}{l}23,545 \\
(100 \%)\end{array}$ & $\begin{array}{l}12,663 \\
(54 \%)\end{array}$ & $\begin{array}{c}7090 \\
(30 \%)\end{array}$ & $\begin{array}{c}3792 \\
(16 \%)\end{array}$ \\
\hline
\end{tabular}

Source: Developed by authors from public corruption cases data set from 1986-2015.

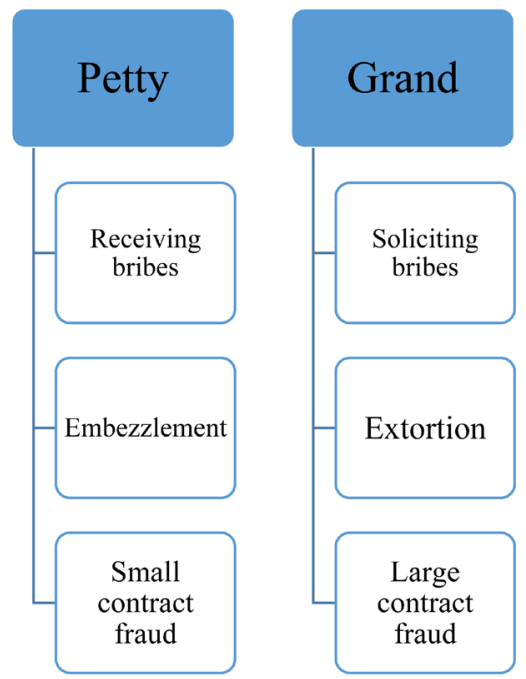

Figure 1. Types of Petty and Grand corruption.

corruption varies: fraud is the most common type of corruption at the federal level, bribery at the local level, and extortion at the state level. The bottom row of Table 2 also indicates that $54 \%$ of all cases involved federal defendants, $30 \%$ involved local defendants, and 16\% involved state-level defendants.

\section{Method}

To examine the motives that underlie these different forms of corrupt behavior, 72 individuals with direct experience in corruption cases were interviewed to provide insider detail into the circumstances of these cases. The individuals interviewed were of four general types presented in Table 3.

Each interviewee agreed to be interviewed with the provision that their identity and comments would be kept confidential, so as not to be linked to them personally. The advantage of this sample of interviewees was that all had first-hand exposure to multiple cases over the course of their lives and careers, so the 72 interviews discussed hundreds of documented corruption cases. Each respondent was asked a series of structured open-ended questions 
Table 3. Interviewee backgrounds.

\begin{tabular}{ccc}
\hline $\begin{array}{c}\text { Interviewee background } \\
\text { (Designations) }\end{array}$ & \multicolumn{2}{c}{ Sample demographics } \\
\cline { 2 - 3 } $\begin{array}{c}\text { Former investigators (I) } \\
\text { (e.g., FBI, State Police) } \\
\text { Former prosecutors (A) } \\
\text { interviews }\end{array}$ & Percentage \\
\hline $\begin{array}{c}\text { (e.g., Department of Justice, State Attorneys) } \\
\text { Individuals who experienced corruption first hand (E) (e.g. } \\
\text { Offenders, Victims, Insiders, Undercover and Whistleblowers) } \\
\text { Public watchdogs (S) }\end{array}$ & 18 & $25 \%$ \\
Total & 14 & $19 \%$ \\
(e.g. Stakeholders, Community Activists, Researchers) & 72 & $25 \%$ \\
\hline
\end{tabular}

and follow-ups over the course of the interview. Potential interviewees were identified via their participation or identification in known cases (using public records---court documents and media accounts), Internet searches, LinkedIn connections, and referrals from other respondents.

Some of the questions during the semi-structured interviews inquired about offender motivation: how did individuals caught up in corruption cases land there? What were the reasons why persons choose to engage in corrupt acts involving bribery, fraud, extortion, or other crimes?

As another way to learn about offender motivation, the researchers also examined a sample of 36 major corruption cases through their court documents, including indictments, pleas, and sentencing memorandums. This analysis of court documents was not as useful as the interviews in speaking to issues of offenders' motivations, because court documents and the legal arguments focus on issues surrounding fact situations and liability. Since motivation is seldom considered an element of the offense, it is given little attention but rather described using terms like "greed," "need to pay personal debts," "to enrich himself," and "personal benefit." The interviews provided deeper explanations and context of offenders' motivations.

Interview transcripts were coded, based on themes covered in the discussion. The interviews were analyzed using MAXQDA qualitative analysis software. The software permits separation and grouping of themes across interviews. This article focuses on the themes of offenders' motivations, character, and circumstances surrounding corruption cases. The initial coding identified the themes of motivation, character and context in the interviews. The axial coding categorized themes to four categories: positivistic, classical, structural and ethical.

\section{Causes of Corruption}

While a great deal has been written about the causes of crime and corruption, only a small proportion of this work focuses on the experiences on those with firsthand exposure to the conduct occurring in cases that result in prosecution. 
Many firsthand accounts are biographical (Abramoff, 2012; Barer, Girardot, \& Eurell. 2016; Chayes, 2015; Hake, 2015; York, 2014). These accounts are interesting, but often focus on a specific case. Consequently, they have limited applicability to wider situations.

The research literature speculates about the causes and correlates of corruption, often using broad macro-level demographic, political and economic variables (Asongu, 2013; d'Agostino, Dunne, \& Pieronic, 2016; Lash \& Batavia, 2013). But the individual perspectives of those actually involved in corruption cases is often lacking, relying instead on macro influences, such as forms of government, public spending rates, salary levels, and other potential correlates of corruption. Firsthand experiences are crucial to consider for they contain primary observations, and often conversations, with the principals in corruption cases. This evidence permits a level of insight into individual decision-making that macro-level analysis of corruption cases cannot provide.

The causes of crime and corruption can be grouped into four categories of explanations, which rely of different assumptions about the genesis of criminal conduct. These categories are positivist, classical, structural, and ethical explanations.

\subsection{Positivist Explanations}

The positivist perspective on criminal motivation corresponds with the rise of social science and the scientific method in the late 1800s. Positivism looks to the internal or external influences on individuals as the cause of criminal or corrupt behavior. Last century, many theories tried to explain crime using a combination of primarily psychological, social, and economic factors (Akers, Sellers, \& Jennings, 2016; Williams \& McShane, 2017). The assumption behind these explanations is that changing the influences on individuals will reduce or prevent the criminal behavior.

Each explanation places emphasis on different aspects of the individuals and their local surroundings. These emphases include factors such as "criminal opportunities" in different settings, "learning" through personal associations that crime is acceptable behavior, peer group pressure, and "neutralizing" the guilt individuals feel about their criminal behavior by rationalizing it (Cloward \& Ohlin, 1960, Matza, 1964; Sutherland, 1939).

Positivistic explanations place greater emphasis on internal or external influences on behavior, rather than on individual decision-making. Therefore, positivistic explanations show conditions that make corruption an easy choice, but do not focus on the decisions to make that choice versus other non-criminal choices.

\subsection{Classicist Explanations}

The classical perspective sees crime as the result of a free-will decision to make a criminal choice. The pain-pleasure principle guides this free-will decision: 
people always will act in a way that maximizes pleasure and minimizes pain. Unlike the positivist, the classicist does not see external influences as dispositive, but instead focuses on the criminal decision itself.

Corrupt behavior is prevented in the classical view when the pain produced with criminal conduct (i.e., likelihood of apprehension and punishment) is greater than the pleasure gained (usually measured by economic gain). Therefore, classicists focus on ways to reduce the probability of gain and increase the possibility of apprehension when corrupt decisions are made. One type of classical approach focuses on "routine activities" or "situational crime prevention." Routine activities theory assumes that crime is determined by several facilitating factors: the availability of attractive targets, a low level of supervision, and low risk of apprehension. Rather than focusing on positivist causes of crime (e.g., poverty, poor education, peer groups), the focus is shifted to ways to reduce the opportunities for crime and minimize their harm by increasing the likelihood of apprehension (and reducing the probability of illicit gain) (Bullock, Clarke, \& Tilley, 2010; Eckblom, 2003).

Situational crime prevention requires that crime prevention techniques be directed at five areas to increase the effort and risk for offenders, while reducing the provocations excuses and rewards for the corrupt behavior. These five emphases are each designed to increase the likelihood of detection, apprehension and reduction in the potential for gain provided by the criminal conduct.

\subsection{Structural Explanations}

The structural approach emphasizes the role played by broader systemic factors, such as the local or even national power structure, corrupt or incompetent government leadership, and the way in which laws are enforced in practice. These factors may not directly cause corruption, but they create the conditions for corruption to flourish.

For example, a lack of power, authoritarian control, incompetence, or corruption in government institutions (such as the operation of the mayor or governor's office, police or sheriff's department, or regulatory agencies) protects existing corruption and nourishes it through ineffective or corrupted rule of law in a jurisdiction. In some locations, systematically corrupt police, judges, licensing agencies, and politicians results in the government structures operating as criminal enterprises extorting bribes, fees, and compliance from citizens and businesses (see Albanese, Artello, \& Ngyuen, 2018). A study of 59 countries found both state and economic failure to be most strongly connected to a corrupt judiciary and the existence of black market activities (Sung, 2004).

The emphasis for structuralist explanations is on the extent to which the operation of government agencies reflects the interests of the public versus the private interests of corrupt officials or corporations. In addition, differences among jurisdictions in the legality of various products and services create opportunities for corruption across borders to capitalize on the differences in laws or their enforcement (e.g., local taxes on cigarettes, gambling and prostitution regulation). 
These differences in legality and how they are enforced create corruption opportunities to exploit (Block \& Chambliss, 1981; Hobbs, 2013; Passas, 2001; Zabyelina, 2014).

\subsection{Ethical Explanations}

The ethical perspective sees crime as a moral failure in decision-making. Corruption occurs when the choice is made to do so, resulting from a failure to appreciate the act's wrongfulness or its impact on the victim. External factors can push an individual in a criminal direction, but there is no classical hedonistic tendency to be corrupt that is controlled by the threat of apprehension and punishment.

The ethical view finds that corruption occurs when individuals place their own self-interest above the interests of others. Short-term gains outweigh an appreciation for the wrongfulness of the conduct and the harm it causes to the victim and the larger community. A person refrains from criminal behavior, in the ethical view, because it does not bring pleasure (Glor \& Greene, 2003; OECD, UNODC, \& World Bank, 2013). Corruption occurs when criminal acts bring pleasure rather than guilt or shame (Albanese, 2016). If low odds of apprehension and punishment were the primary obstacles that prevented corruption, many more people would be corrupt, given the low likelihood of apprehension. The ethical perspective sees more at work in law-abiding behavior than simply the threat of legal and criminal penalties. The failure to comprehend, feel guilty about, and gauge actions by the long-term consequences of the conduct is central to the ethical explanation. Lacking training and experience with ethical decisions, people often do what comes naturally: they make decisions based on their own self-interest and they fail to understand or appreciate the legitimate interests of others or of the community at large (Narvaez, 2006; Nucci, Narvaez, \& Krettenauer, 2014).

Table 4 summarizes how criminal conduct can emanate from different kinds

Table 4. Four approaches to the causes of corruption.

\begin{tabular}{|c|c|c|}
\hline \multirow{2}{*}{$\begin{array}{l}\text { Approach to } \\
\text { causation }\end{array}$} & \multicolumn{2}{|c|}{ Definitions and prevention methods } \\
\hline & Primary cause & Prevention methods \\
\hline $\begin{array}{l}\text { Positivist } \\
\text { (e.g., peer pressure, learning, } \\
\text { opportunity) }\end{array}$ & $\begin{array}{l}\text { External factors (usually social and economic) push } \\
\text { an individual toward crime and corruption. }\end{array}$ & $\begin{array}{l}\text { Reform by changing social and economic } \\
\text { conditions, or by changing a person's reaction to } \\
\text { them. }\end{array}$ \\
\hline $\begin{array}{l}\text { Classical } \\
\text { (e.g., control, routine activities) }\end{array}$ & $\begin{array}{l}\text { A free-will decision to commit corruption is guided } \\
\text { by hedonistic tendency to maximize pleasure and } \\
\text { minimize pain. }\end{array}$ & $\begin{array}{l}\text { Deterrence through increasing the threat of } \\
\text { apprehension and punishment. }\end{array}$ \\
\hline $\begin{array}{l}\text { Structural } \\
\text { (e.g., weak or authoritarian jurisdictions } \\
\text { with unequal law enforcement) }\end{array}$ & $\begin{array}{l}\text { Systemic political and economic conditions in a } \\
\text { jurisdiction that create an environment conducive } \\
\text { to corruption. }\end{array}$ & $\begin{array}{l}\text { Legal and structural changes to election } \\
\text { processes, the balance of power in a jurisdiction, } \\
\text { the enforcement of laws, and ability to file } \\
\text { complaints without fear. }\end{array}$ \\
\hline $\begin{array}{l}\text { Ethical } \\
\text { (e.g., prevent self-interested conduct; } \\
\text { enhance recognition of harm, } \\
\text { wrongfulness }\end{array}$ & $\begin{array}{l}\text { Free-will decisions are guided by ethical principles. } \\
\text { Illegal conduct occurs because it brings pleasure } \\
\text { instead of shame due to its wrongfulness and harm } \\
\text { to the victim and community. }\end{array}$ & $\begin{array}{l}\text { Education and reinforcement of ethical decision } \\
\text { making from an early age, and through job } \\
\text { training and recruitment. Reduction of external } \\
\text { factors that promote unethical decisions. }\end{array}$ \\
\hline
\end{tabular}


of causal influences including ethical, classical, positive, and structural. It can be seen how these different kinds of influences can be present for different individuals facing different situations.

\section{Results}

Table 5 summarizes the results of the interviews in terms of the causal explanations described above. The qualitative interview analysis used a coding scheme to extract every time an interviewee discussed motivations for the corrupt conduct they witnessed or experienced. Results indicated (shown in third column of Table 5) that of the explanations for the first-hand corruption witnessed or experienced by the interviewee, $15 \%$ offered positivist explanation, $19 \%$ a classical explanation, $28 \%$ a structural explanation, and $38 \%$ an ethical explanation.

Excerpts from interviewee responses are also provided in Table 5. The interviewees discussed offender motivation 97 times during the interviews. The percentages in the table reflect the number of times the explanation could be categorized in one of the four perspectives of positivist, classical, structural, or ethical. It can be seen that ethical explanations of corruption were the most common by far $(n=38 \%)$, which was significantly higher than the other categories. Yet, each of the four kinds of explanations was employed in describing different specific corruption cases.

The responses of the interviewees, based on their experience with actual cases, combine to offer empirical insight into the causes of corruption. These insights are valuable because they are based on firsthand exposure to serious corruption cases that were prosecuted in court. Table 5 illustrates that explanations based on ethical failures were the most common, followed by structural, classical, and positivist explanations.

It should be noted that interviewees with exposure to multiple and separate cases (e.g., former investigators, prosecutors, journalists) sometimes identified different causal circumstances in various situations. This finding suggests that different instances of corruption may have quite a few different causes. Rather than a global explanation of corruption, therefore, the findings here suggest that each of these four explanations help to explain the existence of corruption in varying circumstances. Prevention approaches must be responsive to this finding, rather than focusing on limited, specific anti-corruption approaches.

\section{Reducing the Incidence of Corruption}

In all these cases, measures can be taken to reduce their occurrence. Given the analysis here of interviews and case documents, some specific methods to reduce the incidence of underlying behaviors can be recommended. To be effective, recommendation should flow from the identified causes of the corrupt conduct. This process is summarized in Figure 2.

Figure 2 shows how there are different motivations for corruption, and how these motivations can be addressed used different prevention strategies. These 
Table 5. Interviewee assessment of corruption causation.

\begin{tabular}{llc}
\hline & Interview data applied to causation type & Percentage of \\
\cline { 2 - 3 } & Approach to \\
causation & Primary cause identified by interviewee (excerpts from 97 observations) & applied corrupt \\
acts to cause
\end{tabular}

I went along to belong. He tried to justify his actions by calling them scumbag dealers. We were the scumbag dealers. E08

People grow up together in the area. This breeds a greater comfort for the trafficker to approach the cop. They're cousins or friends who went to school, and that makes it okay. A19

Positivist

(e.g., peer pressure, learning, opportunity)

There can be this feeling because they are so low paid, not respected by the community, and not thanked by the community. People verbally abuse them and are not happy to see them. E01

Less and less people with outside incomes are running for office (so they are influenced by the

opportunities to make money as a public official). 013

They know it was wrong and rationalized it. "Everyone does it." 007

I wish I hadn't given in to peer pressure then. 008

The culture views the behavior as normal, which is creating a corrupting influence, and money is a huge factor. A14

Everyone was involved in the thought they could get away with it. E01

People become corrupt through seeing people making lots of money, and people are idiots. "Why am I not getting this?" S03

Their egos to become public officials are great, and so it makes sense that they do not think they're going to get caught. S15

Classical

People see an opportunity and see that when they get in. People run for office have a desire for more power, and

Some people think they will not get caught, and that they are being too smart to get caught. Some people are

(f) careless. E13

If you can get away with that, why not do it? E04

People don't start out bad, but when there are no checks on their judgment and no oversight, corruption can be tempting to receive a financial benefit that they had been entitled to. A08

One doesn't think that they are going to get detected. In their view, detection is unlikely. Even when you are detected, the penalties are not much. A12

Public officials in border areas also think, "I want to get my share." A17

It was a free-for-all in the mayor's office. It was like it was an open bank account with the police, Mayor, and schools. They just get away with it. "Everyone is on the take, so why shouldn't I get mine too?" E01

Structural He appeared to be mayor for life. E01

(e.g., weak or Corruption appears to be related to power relations. S03

authoritarian When I went to the FBI and look [ed] at the backgrounds, the mayor would intercede on the guy's

jurisdictions behalf. E14

with unequal Lewis was holding up an endorsement and support until she got a piece of the pie. E13

law A large minority are corrupted by the dysfunction of the system. It begins with the perks. You get a special

enforcement) license plate. They insist to be called "Senator." E12

"Mayor and I are best friends." E03

Everyone was doing it. To get ahead as attorney, you had to play the game. E07

If a sergeant tells you to drink on the job, as a rookie, you can't say no. You think he's the boss. E08

Some people are attracted to public life because they are attracted to the power. A20

Ethical He used the office to line his own pockets at the expense of the people who needed the funds the most. E01

(e.g., prevent They hurried to recruit and hire police officers. They ended up hiring people who had many issues. E02

self-interested The Kilpatrick family had a history of taking beyond their salary, and they don't think anything's wrong with

conduct; that. S04

enhance The school principals took the bribes because no one thinks it's wrong. S04

recognition of It comes back to the basic character of the individual-lie and cheat and steal at home, you are likely to lie and

harm, cheat and steal at work. S04

wrongfulness White collar defendants and public official defendants because they think they are not doing anything wrong. S17 


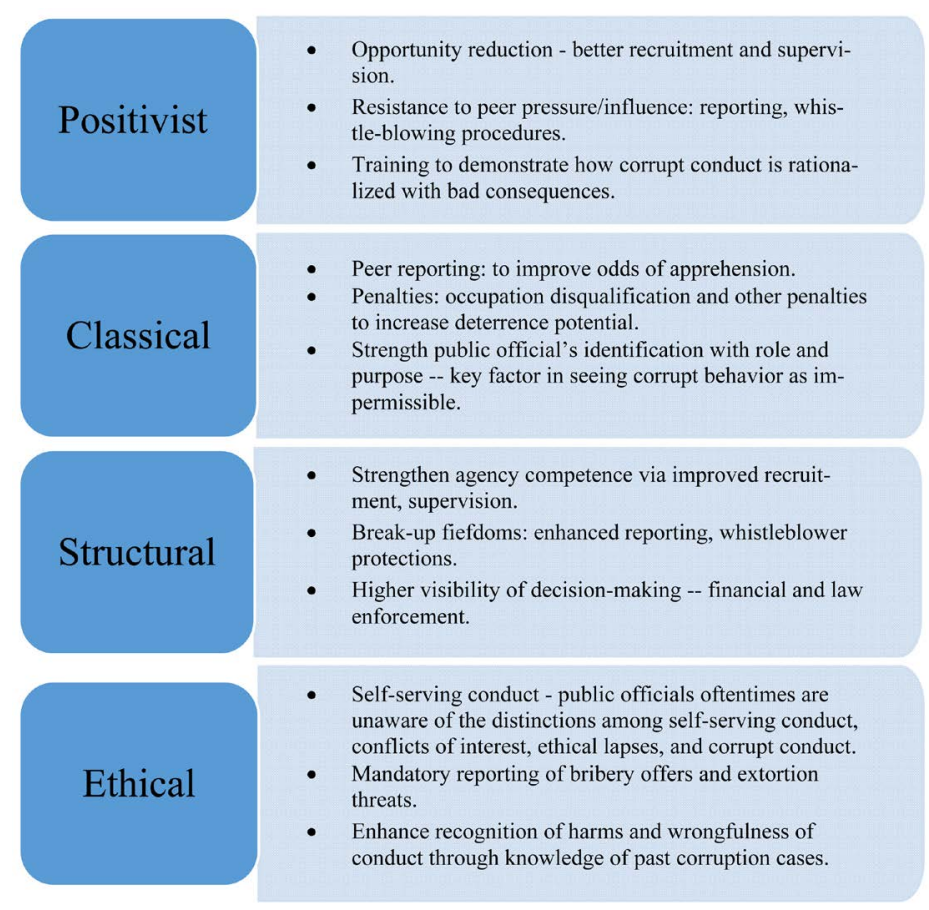

Figure 2. Different corruption prevention approaches required for differing offender motivations.

recommendations for corruption prevention include opportunity reduction through better recruitment and supervision of public officials at all levels.

The strength of public officials' identification with their role and purpose has been shown in other studies to be an important factor in defining corrupt behavior as impermissible (Carucci, 2016; Chayes, 2015; Pisor \& Gurven, 2015). Second, better training of public officials who oftentimes are unaware of the important distinctions among self-serving conduct, conflicts of interest, ethical lapses, and illegal corrupt conduct (Albanese, 2016; Keith \& Campbell, 2012; Salkin \& Ince, 2014). Third, because many cases involved voluntary exchanges and ongoing conspiracies, a more concerted effort should be made to disrupt organized misconduct through better supervision, opportunity reduction, whistleblower protections, and clear understanding of the consequences of this kind of conduct as seen in past cases (See Arrieta, 2016; Erickson \& Hills, 2007; Graycar \& Prenzler, 2013; Lim \& Sloan, 2016). Fourth, existing corrupt conduct and incompetent (or absent) supervision can contribute to a corrupt environment that grows in size and scope (Barer, Girardot, \& Eurell, 2016; Hake, 2015; York, 2014).

\section{Conclusion}

Interviews with 72 former investigators, prosecutors, community stakeholders and individuals with first-hand experience with corruption cases (e.g. offenders, victims, insiders, undercover agents, whistleblowers) reveal the motivations behind corrupt conduct in hundreds of known and prosecuted corruption cases. It 
was found that corrupt motivations could be classified into four categories: positivistic, classical, structural, and ethical. Interviewees identified separate and distinct cases from their experience that saw each of these four types of motivation employed, although ethical shortcoming was identified most often, followed by structural explanations.

These findings suggest that corruption occurring under different circumstances may have quite a few different causes. Therefore, a global explanation of corruption does not appear to exist. The findings of this study indicate that each of these four kinds of explanations of offender motivation helps to explain the existence of corruption in some specific circumstances. Prevention approaches must be responsive to this finding, rather than focusing on limited, specific anti-corruption approaches. Recommendations are made for designing corruption prevention strategies around these identified offender motivations to reduce opportunities for corruption and improve the integrity levels of those in public service.

\section{Acknowledgements}

This project was supported in part by Award No. 2015-IJ-CX-0007, awarded by the National Institute of Justice, Office of Justice Programs, U.S. Department of Justice. The opinions, findings, and conclusions or recommendations expressed in this publication are those of the author(s) and do not necessarily reflect those of the Department of Justice.

\section{References}

Abramoff, J. (2012). Capitol Punishment: The Hard Truth about Washington Corruption from America's Most Notorious Lobbyist. Washington, D.C.: WND Books.

Akers, R. L., Sellers, C. S., \& Jennings, W. G. (2016). Criminological Theories: Introduction, Evaluation, and Application (7th ed.). Oxford: Oxford University Press.

Albanese, J. S. (2016). Professional Ethics: Being Ethical When No One Is Looking (4 ${ }^{\text {th }}$ ed.). Upper Saddle River, NJ: Prentice Hall.

Albanese, J. S., Artello, K., \& Nguyen, L. T. (2018). Distinguishing Corruption in Law and Practice: Empirically Separating Conviction Charges from Underlying Behaviors. Public Integrity. https://doi.org/10.1080/10999922.2018.1423859

American National Election Studies (2012). The ANES Guide to Public Opinion and Electoral Behavior. Ann Arbor, MI: University of Michigan, Center for Political Studies.

Arrieta, L. B. (2016). Attacking Bribery at Its Core: Shifting Focus to the Demand Side of the Bribery Equation. Public Contract Law Journal, 45, 587-612.

Asongu, S. A. (2013). Fighting Corruption in Africa: Do Existing Corruption-Control Levels Matter? International Journal of Development Issues, 12, 36-52. https://doi.org/10.1108/14468951311322109

Barer, B., Girardot Jr., F. C., \& Eurell, K. (2016). Betrayal in Blue. Denver, Colorado: Wild Blue Press.

Belousova, V., Goel, R. K., \& Korhonen, I. (2016). Corruption Perceptions versus Corrup- 
tion Incidence: Competition for Rents across Russian Regions. Journal of Economics and Finance, 40, 172-187. https://doi.org/10.1007/s12197-014-9298-y

Block, A. A., \& Chambliss, W. J. (1981). Organizing Crime. Amsterdam: Elsevier.

Bullock, K., Clarke, R. V., \& Tilley, N. (2010). Situational Prevention of Organised Crimes. Milton Park, Abingdon-on-Thames: Willan Publishing.

Buscaglia, E., \& Dakolias, M. (1999). An Analysis of the Causes of Corruption in the Judiciary. Law and Policy in International Business, 30, 95-116.

Carte, P., \& Fox, C. (2004). Bridging the Culture Gap: A Practical Guide to International Business Communication. London: Kogan Page.

Carucci, R. (2016). Why Ethical People Make Unethical Choices. Harvard Business Review, December 16.

Chayes, S. (2015). Thieves of State: Why Corruption Threatens Global Security. New York City, New York: W.W. Norton \& Company.

Cieslik, A., \& Goczek, L. (2018). Initial Conditions and Privatisation as Causes of Post-Communist Corruption. Post-Communist Economies, 30, 36-55. https://doi.org/10.1080/14631377.2017.1361693

Cloward, R. A., \& Ohlin, L. E. (1960). Delinquency and Opportunity: A Theory of Delinquent Gangs. New York, NY: Free Press.

d'Agostino, G., Dunne, J. P., \& Pieronic, L. (2016). Government Spending, Corruption and Economic Growth. World Development, 84, 190-205. https://doi.org/10.1016/j.worlddev.2016.03.011

De Speville, B. (2016). The Struggle against Corruption: Progress at a Snail's Pace. Why? Asia-Pacific Review, 23, 115-124. https://doi.org/10.1080/13439006.2016.1195963

Deloitte (2017). Deloitte Bribery and Corruption Survey 2017. https://www2.deloitte.com/nz/en/pages/risk/articles/2017-bribery-and-corruption-surv ey.html

Eckblom, P. (2003). Organised Crime and the Conjunction of Criminal Opportunity Framework. In A. Edwards, \& P. Gill (Eds.), Transnational Organized Crime: Perspectives on Global Security (pp. 242-263). London: Routledge.

Erickson, M. M., \& Hills, R. M. (2007). Research on Corruption and Its Control: The State of the Art. Washington DC: The World Bank.

Gallup Poll (2010). Trust in Government. http://news.gallup.com/poll/5392/trust-government.aspx

Glor, E. D., \& Greene, I. (2003). The Government of Canada's Approach to Ethics: The Evolution of Ethical Government. Public Integrity, 5, 39-85. https://doi.org/10.1080/15580989.2003.11770933

Graycar, A., \& Prenzler, T. (2013). Understanding and Preventing Corruption. London: Palgrave Macmillan. https://doi.org/10.1057/9781137335098

Hake, T. (2015). Operation Greylord. Washington DC: ABA Publishing.

Hobbs, D. (2013). Lush Life: Constructing Organized Crime in the UK. Oxford: Oxford University Press. https://doi.org/10.1093/acprof:oso/9780199668281.001.0001

Holmes, L. (2015). Corruption: A Very Short Introduction. Oxford: Oxford University Press. https://doi.org/10.1093/actrade/9780199689699.001.0001

Keith, N., \& Campbell, R. (2012). Anticorruption Legislation. Professional Safety, 57, 46-54.

Lash, N. A., \& Bala, B. (2013). Government Economic Intervention and Corruption. 
Journal of Developing Areas, 47, 1-15. https://doi.org/10.1353/jda.2013.0026

Lim, H., \& Sloan, J. J. (2016). Police Officer Integrity: A Partial Replication and Extension. Policing: An International Journal, 39, 284-301. https://doi.org/10.1108/PIJPSM-10-2015-0127

Matza, D. (1964). Delinquency and Drift. Hoboken: Wiley.

Moldovan, A., \& Van de Walle, S. (2013). Gifts or Bribes? Public Integrity, 15, 385-402.

Narvaez, D. (2006). Integrative Ethical Education. In M. Killen, \& J. Smetana (Eds.), Handbook of Moral Development (pp. 703-733). Mahwah, NJ: Lawrence Erlbaum Associates.

Nucci, L., Narvaez, D., \& Krettenauer, T. (2014). Handbook of Moral and Character Education (2d ed.). Abingdon-on-Thames: Routledge.

OECD Convention (1999). OECD Convention on Combating Bribery of Foreign Public Officials in International Business Transactions. http://www.oecd.org/corruption/oecdantibriberyconvention.htm

OECD, UNODC, \& World Bank (2013). Anti-Corruption Ethics and Compliance Handbook for Business. http://www.oecd.org/corruption/Anti-CorruptionEthicsComplianceHandbook.pdf

Passas, N. (2001). Globalization and Transnational Organized Crime: Effects of Criminogenic Asymmetries. In P. Williams, \& D. Vlassis (Eds.), Combating Transnational Organized Crime: Concepts, Activities and Responses (pp. 22-56). London: Frank Cass.

Pisor, A. C., \&Gurven, M. (2015). Corruption and the Other(s): Scope of Superordinate Identity Matters for Corruption Permissibility. PLoS ONE, 10, e0144542. https://doi.org/10.1371/journal.pone.0144542

Reider-Gordon, M. (2011). U.S. and International Anti-Money Laundering Developments. The International Lawyer, 25, 365-379.

Rose-Ackerman, S., \& Palifka, B. J. (2016). Corruption and Government: Causes, Consequences, and Reform (2d ed.). Oxford: Oxford University Press.

Salkin, P., \& Ince, B. (2014). It's a "CrimingChame": Moving from Land Use Ethics to Criminalization of Behavior Leading to Permits and Other Zoning Related Acts. Urban Lawyer, 46, 249-267.

Sung, H. (2004). State Failure, Economic Failure, and Predatory Organized Crime: A Comparative Analysis. Journal of Research in Crime \& Delinquency, 41, 111-129. https://doi.org/10.1177/0022427803257253

Sutherland, E. H. (1939). Principles of Criminology. New York, NY: Lippincott.

Tanzler, D., Konstadinos, M., \& Giannakouplos, A. (2016). The Social Construction of Corruption in Europe. Hoboken: Routledge.

Transparency International (2011). Bribe Payers Index 1999-2011. https://www.transparency.org/research/bpi/overview

Transparency International (2017). Corruption Perceptions Index 2016. http://www.transparency.org/

United Nations Convention on Corruption (2005). https://www.unodc.org/unodc/en/corruption/uncac.html

White, R. (2013). What Counts as Corruption? Social Research, 80, 1033-1056.

Williams III, F. P., \& McShane, M. D. (2017). Criminological Theory(7th ed.). New York, NY: Pearson.

World Bank (1997). Helping Countries Combat Corruption: The Role of the World Bank. http://www1.worldbank.org/publicsector/anticorrupt/corruptn/cor02.htm 
York, G. (2014). Corruption behind Bars: Stories of Crime and Corruption in Our American Prison System. London: Independent.

Zabyelina, Y. (2014). The "Fishy" Business: A Qualitative Analysis of the Illicit Market in Black Caviar. Trends in Organized Crime, 17, 181-198.

https://doi.org/10.1007/s12117-014-9214-z 